\title{
THE COMPENSATION AND EFFICIENCY HYPOTHESES: NEW EVIDENCE FOR TURKEY WITH RALS COINTEGRATION AND BOOTSTRAP CAUSALITY TESTS
}

\author{
Zerrin KILIÇARSLANa
}

D Cüneyt DUMRUL
Yasemin DUMRULc

\begin{abstract}
Together with trade openness and globalization, the risks and uncertainties faced by countries are also increasing. Government expenditure is one of the important policy tool used to minimize the effects of these risks. Increases and decreases in government expenditures due to openness and globalization are examined in the literature within the framework of compensation and efficiency hypotheses. In this study, the validity of Turkey's compensation and efficiency hypotheses was examined using annual data for the period 1970-2018 and RALS co-integration and bootstrap causality tests. The results of the analysis support the efficiency hypothesis, which states that the increase in trade openness affects government expenditures negatively, and the compensation hypothesis, which states that the increase in globalization increases government expenditures. In addition, according to the results of the bootstrap causality test, there is a one-way causality relationship from trade openness to government expenditures.

Keywords: Government size, Globalization, Trade openness, RALS co-integration test, Bootstrap causality test

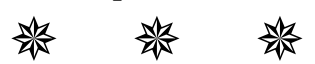

\section{TELAFI VE ETKINLIKK HIPOTEZİ: RALS EŞ-BÜTÜNLEŞME VE BOOTSTRAP NEDESENLLİK TESTLERI İLE TÜRKIYYE İÇIN YENI KANITLAR \\ Özet}

Dışa açıklık ve küreselleşme ile birlikte ülkelerin karşılaştıkları risk ve belirsizlikler de artmaktadır. Kamu harcaması, söz konusu risklerin etkilerini en aza indirmek amacıyla kullanılan önemli politika araçlarından biridir. Dışa açıklık ve küreselleşmeye bağlı olarak ortaya çıkan kamu harcama artış ve azalışları literatürde telafi ve etkinlik hipotezleri çerçevesinde incelenmektedir. Bu çalışmada Türkiye'de etkinlik ve telafi hipotezinin geçerliliği 1970-2018 dönemi yıllık verileri ile RALS eş-bütünleşme ve bootstrap nedensellik testleriyle incelenmiştir. Analiz sonuçları ticari açıklıktaki artışın kamu harcamalarını negatif etkilediğini ifade eden etkinlik hipotezini ve küreselleşmedeki artışın kamu harcamalarını artırdığını ifade eden telafi hipotezini

\footnotetext{
a Doç. Dr., Kayseri Üniversitesi, Teknik Bilimler Meslek Yüksekokulu, Pazarlama ve Diş Ticaret Bölümü, zerrink@kayseri.edu.tr

b Doç. Dr., Erciyes Üniversitesi İktisadi ve İdari Bilimler Fakültesi, İktisat Bölümü, cdumrul@erciyes.edu.tr

c Doç. Dr., Develi Hüseyin Şahin Meslek Yüksekokulu, Büro Hizmetleri ve Sekreterlik Bölümü, ydumrul@kayseri.edu.tr Makale Geliş Tarihi: 21.10.2021, Makale Kabul Tarihi: 28.11.2021
} 
desteklemektedir. Ayrıca bootstrap nedensellik testi sonucuna göre ticari açıklıktan kamu harcamalarına doğru tek yönlü bir nedensellik ilişkisi bulunmaktadır.

Anahtar Kelimeler: Hükümet büyüklüğü, Küreselleşme, Ticari açıklık, RALS Eş-bütünleşme testi, Bootstrap nedensellik testi

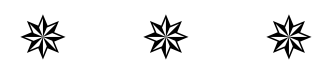

\section{Introduction}

Globalization, which can also be expressed as the process of opening up countries, can be defined as creating connection networks between actors at intercontinental distances through various flows, including people, information and ideas, capital, and goods. Therefore, globalization is a multifaceted concept that includes economic, social, and political aspects beyond indicators such as trade openness and capital movements (Garrett, 1998; Kim et al., 2018).

Globalization and openness bring various external risks. The country's citizens may be adversely affected by this process, and the country's citizens may encounter various risks arising from these processes. One of the issues that economists discuss is how openness will create risks for economies and determine the policies to be applied for the risks encountered (Özek \& Bayat, 2020, p. 720). In this context, government expenditures emerge as an important policy tool that governments use to protect their economies from these risks. Due to globalization, increases and decreases in government expenditures are examined in the literature with two basic hypotheses, namely compensation and efficiency (Altay \& Aysu, 2013, p. 132).

The compensation hypothesis is that the state increases government expenditures to protect the country's citizens from the external risks that will arise due to globalization. Rodrik (1998) argued that the opening up of countries would increase government expenditures because the expansion in government expenditures can compensate for the possible welfare decreases. On the other hand, the "efficiency hypothesis" expresses that the openness and globalization process will reduce government expenditures rather than increase them (Genç \& Telatar, 2015, p. 442).

Making analyses for the validity of compensation and efficiency hypotheses is important in directing the countries' economic policies. In this context, some studies in the literature (Altay \&Aysu, 2013; Aydoğuş \& Topçu, 2013; Benarroch \& Pandey, 2008; Cameron, 1978; Rodrik, 1998; Kueh et al., 2008), have analyzed the relationship between trade openness and government size, and some studies (Anderson \& Obeng, 2021; Dreher et al., 2008; Kim, 2018; Meinhard \& Potrafke, 2012; Potrafke, 2009) have analyzed the relationship between globalization and government size.

This study aims to examine the efficiency and compensation hypotheses used to explain the relationship between government size and globalization in the case of Turkey in the period 19702018. This study differs from other studies in the literature in two aspects. First, unlike other studies, both trade openness and KOF general globalization index are used as globalization indicators in the analysis. As a matter of fact, although the trade openness variable as an indicator of globalization in the literature is widely used, the number of studies in which a globalization index value is used is quite limited. 
Second, the RALS technique used to test the efficiency and compensation hypotheses is one of the new techniques in the literature. In addition, the direction of the relationship between the variables was determined by the bootstrap causality test. Methodologically, the number of studies analyzing the direction of the relationship is limited in the studies investigating the causal relationship between the variables of trade openness or globalization and government size. The rest of the study is as follows: In the second section, the theoretical relationship between openness and government size is explained within the framework of the compensation hypothesis and efficiency hypotheses. The third section presents a summary of the literature on the studies testing the compensation and efficiency hypotheses. The fourth section gives information about the data set and econometric methodology used in the study. In the fifth section, empirical findings obtained as a result of the empirical analysis are presented. In the last section, the results of the study are evaluated.

\section{A. OPENNESS AND GOVERNMENT SIZE}

In the literature, the relationship between trade openness and government size is examined under the "compensation" and "efficiency" hypotheses, which explain the opposite of each other in terms of the direction of the effect. The compensation hypothesis assumes a "complementary" relationship between these two variables, and the efficiency hypothesis assumes a "substitution" relationship between government spending and trade openness (Pata \& Yurtkuran, 2020, p. 84).

\section{The Compensation Hypothesis}

With globalization, economic insecurity and uncertainty increase, and countries may be exposed to greater risks due to volatility in the global economy. Therefore, open economies remain vulnerable to external supply and demand shocks, and governments take various measures to compensate for these risks (Zakaria \& Shakoor, 2011, p. 329). Governments use various policy tools to protect their economies from risks in the international market (Cameron, 1978, p. 1260). Government spending is an important tool used to minimize external risks caused by the trade deficit.

The first study on the relationship between openness and government size was conducted by Cameron (1978). According to Cameron (1978), there is a more significant increase in government size in countries with open economies than closed economies. Accordingly, countries with an open economy carry out high government expenditures to address the negative effects of external dependence (Cameron, 1978, p. 1253). According to Cameron (1978), who argues that there is a positive relationship between openness and government size, the structural characteristics of trade openness consist of four stages: the degree of industry concentration, the intensity of unionization, the scope of collective bargaining, and the strength of labor confederations. In a country with an open economy, the level of industrial concentration is increasing. This situation leads to an increase in unionization, widening the

| 1520 | scope of collective agreements and increasing the power of labor confederations. Thus, expenditures on livelihoods increases and the public economy expands. The study of Cameron (1978) was developed by Rodrik (1998), and the results obtained began to be called the "compensation hypothesis". According to Rodrik (1998), since government expenditures will have a risk-reducing effect in economies exposed to significant external risk, trade openness positively affects government size. Rodrik (1998) associates an 
increase in government size to compensate for the volatility caused by trade openness and argues that open countries will also have larger government sectors. According to Rodrik (1998), since external shocks and uncertainties will increase in open economies, the demand for government expenditures such as social security and social assistance will compensate for the increased external risk. In other words, government expenditures will function as social insurance against external risks (Rodrik, 1998, p. 997).

The compensation hypothesis is demand-side due to the increase in social security expenditures and the increase in the government sector's share in the economy (Gemmel et al., 2008, p. 152). The compensation hypothesis emphasizes the possibility that those who suffer from globalization will demand more government spending to mitigate the negative consequences of globalization (Gastaldi \& Liberati, 2009, p. 8). According to the demand-side compensation hypothesis, the government compensates the losses of the segments aggrieved by globalization by realizing social welfare programs with its gains (Dreher et al., 2008, p. 264; Pata \& Yurtkuran, 2020, p. 83).

\section{Efficiency Hypotheses}

Cusack's (1997) study is the first in the literature to propose the efficacy hypothesis. Contrary to the compensation hypothesis, the "efficiency hypothesis" negatively affects government expenditures of open economies. This hypothesis argues that the government's use of its revenues through taxation and borrowing to finance government expenditures negatively affects the economy (Gözgör et al., 2019; Özek \& Bayat, 2020; Pata \& Yurtkuran, 2020).

The basic tenet of the efficiency hypothesis is that government expenditures, beyond measures such as defense, securing property rights, and other essential public goods, reduce national producers' competitiveness of international goods and services markets (Garrett, 2001, p. 5). Investors want to invest their capital in the country with the highest net income to earn more returns. For this reason, in a globalizing world, financial capital can move from countries with high taxes to countries with lower taxes and higher returns. Governments make reductions in various taxes such as corporate tax and income tax to attract more capital. In this case, trade openness tends to reduce the size of the public sector. The supply-side efficiency hypothesis states that taxes on capital and the share of the public sector in the economy are reduced to attract more investment (Pata \& Yurtkuran, 2020, p. 83).

There are two effects of globalization under the supply-side efficiency hypothesis. First, as governments compete to attract mobile capital, they direct government expenditures towards productive public inputs such as education, training, $R \& D$, and infrastructures. Second, the international mobility of capital and income taxpayers weakens the fiscal autonomy of nation-states. As a result, tax revenues and thus total expenditures decrease (Gemmel et al., 2008). In other words, greater exposure to international capital flows means more government pressure to reduce their expenditures due to lower tax revenues (Anderson \& Obeng, 2020, p. 1145).

According to the efficiency hypothesis, there is a negative relationship between trade openness and government expenditures in the case of foreign trade, both as a result of external technological innovations in transport and communication and because of economies of scale and comparative advantage benefits, etc. (Garrett, 2001, p. 5). In other words, the efficiency hypothesis argues that public 
revenues and expenditures can be reduced by reducing the state's tax rates to support the international competition of domestic industries and opening up (Pata \& Yurtkuran, 2020, p. 84).

\section{B. LITERATURE REVIEW}

There is no consensus in the literature about the effect of trade openness on government size. The empirical studies show that trade openness and globalization have different and contradictory impact on government expenditures. While some of the studies found a unilateral relationship between trade openness and government size, in others, no association was found between these variables (Benarroch \& Panday, 2012). Iversen and Cusack (2000) argue that the relationship between trade openness and government size is spurious. The lack of a direct causal relationship between trade openness and government size is called the "deindustrialization hypothesis". In addition, the absence of a relationship between these two variables in the literature is interpreted as the two variables balancing each other (Garrett, 2001, p. 7).

As seen in Table 1, studies in the literature support the compensation hypothesis, which suggests a positive relationship between government expenditures and trade openness. The efficiency hypothesis suggests a negative relationship between these two variables. In addition, the studies in the literature are presented in Table 1 by subjecting them to a dual classification. While Panel A shows studies examining the relationship between trade openness and government size, Panel B shows the studies carried out by considering the KOF variable as an indicator of globalization and deals with the relationship between globalization and government size.

Table 1. Literature Survey

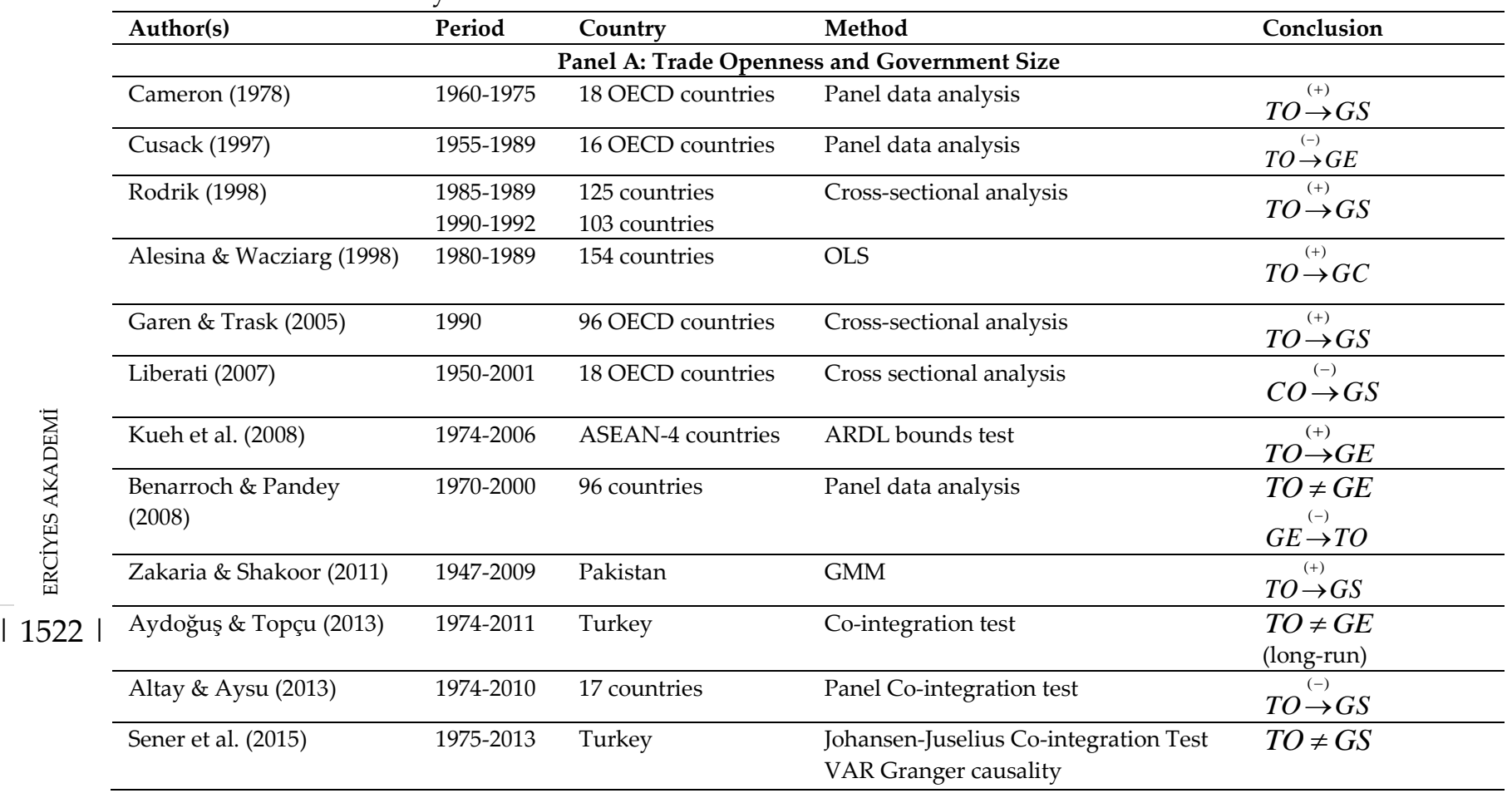


Table 1 (continued)

\begin{tabular}{|c|c|c|c|c|}
\hline \multicolumn{5}{|c|}{ Panel B: Globalization and Government Size } \\
\hline Dreher et al. (2008) & $1971-2001$ & 60 countries & $\begin{array}{l}\text { Combined cross-section time- } \\
\text { series }\end{array}$ & $K O F \neq G E$ \\
\hline Potrafke (2009) & 1980-2003 & 20 OECD countries & Panel data analysis & $K O F \neq S E$ \\
\hline Meinhard \& Potrafke (2012) & $1970-2004$ & 186 countries & Panel data analysis & $\begin{array}{l}\text { KOFoverall } \stackrel{(+)}{\rightarrow} G E \\
\text { KOFeco } \stackrel{(+)}{\rightarrow} G E \\
\text { KOFsoc } \stackrel{(+)}{\rightarrow} G E \\
\text { KOFpol } \stackrel{(+)}{\rightarrow} G E\end{array}$ \\
\hline Kim et al. (2018) & 1980-2011 & 53 countries & $\begin{array}{l}\text { Panel co-integration test } \\
\text { Panel Granger causality test }\end{array}$ & $\begin{array}{l}\text { KOFoverall } \stackrel{(-)}{\rightarrow} G E \\
\text { KOFtrade } \stackrel{(+)}{\rightarrow} G E \\
\text { KOFfin } \stackrel{(-)}{\rightarrow} G E \\
\stackrel{(-)}{\rightarrow} G E \\
\text { KOFsoc } \rightarrow \text { GE }\end{array}$ \\
\hline Yildız (2019) & 1995-2015 & 27 OECD countries & Panel data analysis & $\begin{array}{l}\text { KOFoverall } \rightarrow G E \\
\text { KOFpol } \rightarrow \text { } \rightarrow G E \\
\text { KOFeco } \rightarrow G E \\
\text { KOFsoc } \rightarrow G E \\
\text { KOFpol } \leftrightarrow G E\end{array}$ \\
\hline Anderson \& Obeng (2021) & $\begin{array}{l}1972-20141992- \\
2014\end{array}$ & $\begin{array}{l}116 \text { countries } \\
137 \text { countries }\end{array}$ & $\begin{array}{l}\text { The two-way fixed-effects } \\
\text { method with Driscoll-Kraay } \\
\text { standard errors }\end{array}$ & $\begin{array}{l}\text { KOFTrdj } \stackrel{(+)}{\rightarrow} G E \\
\text { KOFFidj } \stackrel{(-)}{\rightarrow}^{\rightarrow} G E \\
\text { KOFTrdf } \stackrel{(+)}{\rightarrow} G E\end{array}$ \\
\hline
\end{tabular}

Note: GC: government consumption, KOF: globalization index, TO: trade openness, CO: capital openness, SE: social expenditure, GS: government size, GE: government expenditure. $\rightarrow$ : one-way causality relationship, $\leftrightarrow$ : bidirectional causality relationship, $\neq$ : no causality.

\section{EMPIRICAL ANALYSIS}

\section{Data}

In this study, the relationship between government size, trade openness, and globalization is examined in the case of Turkey for the period 1970-2018. General government final consumption expenditures (\%GDP) are used as the government size variable. Some studies on compensation and efficiency hypotheses have analyzed the relationship between trade openness and government size in the literature, and some studies have analyzed the relationship between globalization and government size. In this study, both variables are included in the analysis. Although the concepts of globalization and trade openness are used interchangeably, their contents are different from each other. Globalization is a more comprehensive concept than trade openness as it includes many indicators of economic, social, political, and financial nature. As globalization variables, general globalization variables including commercial globalization and economic, social, and political globalization were included in the analysis. The trade openness variable, expressed as the ratio of total imports and exports to GDP, represents trade 
globalization. The KOF overall globalization index, which includes economic, social, and political globalization, represents general globalization. In the study, government size is defined as a function of trade openness and general globalization. The government size and trade openness data used in this study were obtained from the World Development Indicators (WDI). The KOF overall globalization index is obtained from the Swiss Economic Research Institute. All variables are included in the model by taking their logarithms. The model examined in this study is shown in equation (1).

$$
\ln G E_{t}=\alpha_{0}+\beta_{1} \ln T O_{t}+\beta_{2} \ln K O F_{t}+\varepsilon_{t}
$$

In the above Equation, the variable lnGE represents the logarithm of government size, the variable $\operatorname{lnTO}$ the logarithm of trade openness, and the variable lnKOF the logarithm of the overall KOF variable. $\alpha$ is the constant term, and $\beta$ is the coefficients for the explanatory variables, and $\varepsilon$ is the error term.

\section{Econometric Methodology}

This study is built on the RALS (Residual Augmented Least Squares) technique. The RALS technique is a powerful estimation method used when the residuals of the relevant model are not normally distributed, based on this non-normal distribution information. When the studied series are not normally distributed, the findings obtained by classical methods are biased. Many economic series are also not normally distributed. For this reason, it is more appropriate to use tests containing the RALS technique, which will give more effective results. The method of the study consists of four stages: determining the stationarity level of the variables, revealing the long-term relationship, obtaining the long-term coefficients, and determining the causality relationship. In this context, firstly, the RALS-ADF unit root test is used to determine the stationarity level of the variables. This test adopts the RALS technique proposed by Im and Schmidt (2008) to the ADF unit root test. Im et al., (2014) mathematical model related to the RALS ADF unit root test is presented in Equation (2) (Im et al., 2014, p. 321).

$$
\Delta Y_{t}=\alpha_{1}+\alpha_{2} t+\beta Y_{t-1}+\sum_{j=1}^{p} \delta_{j} \Delta Y_{t-j}+\hat{w}_{t}^{\prime} \gamma+v_{t}
$$

The term in Equation (2) refers to the RALS term, which reflects the information that may arise if the model's residuals are not normally distributed to the ADF unit root model.

$$
\hat{w}_{t}=\left[\hat{e}_{t}^{2}-m_{2}, \hat{e}_{t}^{3}-m_{3}-3 m_{2 t} \hat{e}_{t}\right] t=1,2,3, \ldots, T
$$

The first term in equation (3) $\hat{w}_{t}$ is related to the constant variance condition $E=\left[\left(e_{t}^{2}-\sigma_{e}^{2}\right) y_{t-1}\right]=0$. If the error terms are not symmetric, the first term here increases the

efficiency of the estimator $\beta$. The second term in Equation (3) $\hat{w}_{t}$ improves efficiency unless $\mu_{4}=3 \sigma^{4}$ , where $\mu_{j}=E\left(e_{t}^{j}\right)$. This second term increases the efficiency of the $\beta$ estimator. Thus, both terms positively affect the strength of the test (Im et al., 2014, p. 323). Critical values are determined according to the correlation coefficient $\left(\hat{\rho}^{2}\right)$ between the ADF and the residuals obtained from the RALS-ADF regressions. The calculation related to this is shown in Equation (4). 


$$
\hat{\rho}^{2}=\hat{\sigma}_{A}^{2} / \hat{\sigma}^{2}
$$

$\hat{\sigma}^{2}$, is the error variance obtained from the ADF; $\hat{\sigma}_{A}^{2}$, shows the error variance obtained from RALSADF (Im et.al, 2014, p. 322).

After determining the degrees of stationarity of the variables, the RALS Engle-Granger (RALS-EG) co-integration test developed by Lee et al. (2015) was used to determine whether there is a long-term relationship between the variables. This test is an adaptation of the RALS technique proposed by Im and Schmidt (2008) to the Engle-Granger test. Lee et al. (2015) stated that high moments of non-normally distributed residuals would contain information about the nature of these residuals, and stronger cointegration tests can be derived if this information is used. In the RALS-EG test, the model in which the stability of the residuals is tested in the EG test is expanded by adding the term in Equation (5) (Lee et al., 2015, p. 401).

$$
\hat{w}_{t}=h\left(\hat{e}_{t}\right)-\hat{\ddot{K}}-\hat{e}_{t} \hat{D}_{t} t=1,2,3, \ldots, T
$$

where $h\left(\hat{e}_{t}\right)=\left[\hat{e}_{t}^{2}, \hat{e}_{t}^{3}\right]^{\prime}, \hat{K}=\frac{1}{T} \sum_{t=1}^{T} h\left(\hat{e}_{t}\right)$ and $\hat{D}_{t}=\frac{1}{T} \sum_{t=1}^{T} h^{\prime}\left(\hat{e}_{t}\right)$.

where, $m_{j}=T^{-1} \sum_{t=1}^{T} \hat{e}_{t}^{j} \cdot e_{t}$ indicates the residuals of the regression model tested.

After revealing the long-term relationship between the variables, parameter sizes are determined by FMOLS (Fullly-modified Ordinary Least Square) developed by Phillips and Hansen (1990), DOLS (Dynamic Ordinary Least Square) developed by Stock and Watson (1993), and Park (1992) determined by the developed CCR (Canonical cointegrating regressions) methods. These tests produce strong predictions even in externality and autocorrelation problems and give better results for small samples. In this study, Hacker and Hatemi-J (2012) bootstrap causality test, a more reliable test than other causality tests used in the literature, is applied for small samples to determine the causal direction relationship between the variables. In this test, which is the development of the Toda-Yamamoto causality test, the critical values to be used against the risk of normal distribution of error terms are obtained by bootstrap Monte Carlo simulation. The VAR(k) model used by Hacker and Hatemi-J (2012) to test Granger causality is shown in Equation (6) (Hacker \& Hatemi-J, 2012, p. 146).

$$
y_{t}=\mathrm{B}_{0}+\mathrm{B}_{1} y_{t-1}+\ldots+\mathrm{B}_{k} y_{t-k}+u_{t}
$$

where, $n \times 1$ dimensional vector, and respectively, is the $n \times n$ dimensional coefficient matrix, representing the error vector with an expected zero value. The element in row $j$ and column $r$ of $B_{i}$ is equal to zero. $i=1, \ldots, k$. (Hacker \& Hatemi-J, 2012, p. 146).

Determining the optimal lag length in causality tests is important as it may affect the test result. In Hacker and Hatemi-J (2012) bootstrap causality test, the optimal lag length is determined endogenously. 
In Hatemi-J (2003, 2008), a new knowledge criterion is proposed in testing the causality relationship. This information criterion, which is expressed as HJC, is obtained by combining Schwarz's (1978) and Hannan and Quinn (1979) information criteria. The Hatemi-J information criterion is shown in Equation (7) (Hatemi-J \& Uddin, 2014, p. 377).

$$
\begin{aligned}
H J C & =\operatorname{In}\left(\operatorname{det} \hat{\Omega}_{j}\right)+j\left(\frac{n^{2} \ln T+2 n^{2} \ln (\ln T)}{2 T}\right) \\
& j=0, \ldots, p
\end{aligned}
$$

where, represents the determinant of the estimated maximum likelihood variance-covariance matrix of residuals in the VAR (j) model. The number of variables is $n$, and the sample size is $T$. $\ln$ indicates the natural logarithm (Hatemi-J \& Uddin, 2014,p. 377).

\section{EMPIRICAL FINDINGS}

\section{Unit root test results}

In this study, RALS-ADF unit root test is applied as unit root test. This test is built on the assumption that the residuals of the model are not normally distributed. Therefore, Jarque-Bera normality test is applied before the unit root test. Descriptive statistics for government size, trade openness, and KOF overall globalization, including the Jarque-Bera normality test, are shown in Table 2.

Table 2. Descriptive Statistics

\begin{tabular}{lcccccc}
\hline Variables & Mean & Median & Maximum & Minimum & Std.Dev. & Jarque-Bera (prob) \\
\hline GE & 2.456914 & 2.495241 & 2.758134 & 2.016967 & 0.185081 & $0.050824^{* *}$ \\
TO & 3.482081 & 3.628729 & 4.135925 & 2.208246 & 0.520025 & $0.081323^{* *}$ \\
KOF & 4.006712 & 4.076740 & 4.278666 & 3.684458 & 0.208720 & $0.028284^{*}$ \\
\hline
\end{tabular}

Note: ${ }^{*}$ and ${ }^{* *}$ indicate that the residues are not normally distributed at the $5 \%$ and $10 \%$ significance levels, respectively.

As it can be seen from Table 2, the government size variable is on average $2.46 \%$ between 1970 and 2018. The highest value for government size is $2.76 \%$, and the lowest value is $2.02 \%$. The trade openness variable is on average 3.48\% between 1970 and 2018. The highest value for the trade openness variable is $4.14 \%$, and the lowest value is $2.20 \%$. The KOF overall variable is on average $4.01 \%$ over the period 1970 2018. The highest value for the KOF overall variable is $4.28 \%$, and the lowest value is $3.68 \%$. According to the results of Jarque-Bera test statistics, the residuals of the variables considered in this study do not show a normal distribution. In this case, where the residues are not normally distributed, using the RALSADF test as a unit root test will provide more effective results. RALS-ADF unit root test results are shown in Table 3.

The null hypothesis regarding the applied unit root test is that the series have unit roots under the assumption that the residuals are not normally distributed. The alternative hypothesis, on the other hand, shows that the series is stationary under the assumption that the residuals are not normally distributed. Critical values for the RALS-ADF test are taken from Im et al. (2014). When the asymptotic critical values used in the RALS-ADF unit root test are compared with the calculated $t$ statistical value, it is seen that the variables considered are not stationary, and they become stationary by taking the first difference. 
Table 3 also includes the ADF test results, and it has been seen that all the variables, which are handled similarly to the RALS-ADF test, are stationary by taking the first difference, not at their level.

Table 3. Unit root test results

\begin{tabular}{lllll}
\hline Variables & ADF & RALS-ADF & $\rho^{2}$ & $\mathrm{k}$ \\
\hline $\ln G E$ & -1.250552 & -1.116051 & 0.998785 & 0 \\
\hline $\ln T O$ & -1.793547 & -1.394651 & 0.857900 & 0 \\
\hline $\ln K O F$ & -1.099958 & -0.708520 & 0.935695 & 0 \\
\hline$\Delta \ln G E$ & -6.446166 & -6.372017 & 0.974084 & 0 \\
\hline$\Delta \ln T O$ & -5.951229 & -5.718793 & 0.766522 & 0 \\
\hline$\Delta \ln K O F$ & -6.215231 & -6.373769 & 0.923281 & 0 \\
\hline
\end{tabular}

Note: $k$; is the optimal lag length obtained by the general-to-specific $t$-significance method. The critical values of the ADF test are -3.574 , -2.923 and -2.599 at $1 \%, 5 \%$ and $10 \%$ significance levels, respectively. The critical values of the RALS-ADF test are $-3.750,-3.303$, and -3.053 at $1 \%, 5 \%$, and $10 \%$ significance levels, respectively.

\section{Co-integration Test Results}

Since all the variables used in the study are I(1), EG, and RALS-EG, co-integration tests are applied in the next step to determine whether there is a long-term relationship between the variables. Critical values for the RALS-EG test are taken from Yilancı and Aydın (2018). The co-integration test results are given in Table 4.

Table 4. Co-integration test results

\begin{tabular}{lllc}
\hline & t-statistics & $\mathrm{k}$ & $\rho^{2}$ \\
\hline EG & -4.082171 & 0 & - \\
\hline RALS-EG & -5.746239 & 0 & 0.837301 \\
\hline
\end{tabular}

Note: $\mathrm{k}$ is the appropriate lag length obtained by the general-to-specific t-significance method. The critical values of the EG test are 3,577, $-2,925,-2,600$ at $1 \%, 5 \%$, and $10 \%$ significance levels, respectively. The critical values of the RALS-EG test are $-4.230,-3.610$, and -3.292 at $1 \%, 5 \%$, and $10 \%$ significance levels, respectively.

The null hypothesis of the applied co-integration test is that there is no co-integration relationship under the assumption that the residuals are not normally distributed, and the alternative hypothesis is that there is a co-integration relationship under the assumption that the residuals are not normally distributed. Since the t-statistics values calculated according to both EG and RALS-EG tests are larger than the table value, it is seen that there is a co-integration relationship between the series. In other words, there is a long-run relationship between government size, trade openness, and general globalization.

\section{Long-run Coefficient Estimation Results}

In Table 5, FMOLS, DOLS, and CCR results are given to determine the size of this long-term relationship.

FMOLS, DOLS, and CCR test results applied to obtain long-term coefficients for the variables are very close to each other. According to FMOLS, DOLS, and CCR methods, a 1\% increase in trade openness leads to an approximately $0.6 \%$ decrease in government size. This result is consistent with the studies of 
Cusack (1997), Liberati (2007), Altay and Aysu (2013); a 1\% increase in overall globalization results in an approximately $1.8 \%$ increase in government size. This result is consistent with the study of Meinhard and Potrafke (2012). In addition, the coefficients obtained as a result of the analysis are statistically significant.

Table 5. Long-run coefficient results

\begin{tabular}{|c|c|c|c|c|}
\hline \multicolumn{5}{|c|}{ FMOLS Test Results } \\
\hline \multirow[t]{2}{*}{ Variables } & \multicolumn{4}{|c|}{ Dependent Variable: $\ln G E$} \\
\hline & Coefficient & Standard Error & t-statistics & Prob \\
\hline $\ln T O$ & -0.570374 & 0.074583 & -7.647473 & 0.0000 \\
\hline $\ln K O F$ & 1.866116 & 0.181358 & 10.28969 & 0.0000 \\
\hline \multirow[t]{2}{*}{$C$} & -3.023369 & 0.506687 & -5.966938 & 0.0000 \\
\hline & $R^{2}$ & 0.738625 & $A d j . R^{2}$ & 0.72701 \\
\hline \multicolumn{5}{|c|}{ DOLS Test Results } \\
\hline \multirow[t]{2}{*}{ Variables } & Dependent Variable: 1 & & & \\
\hline & Coefficient & Standard Error & t-statistics & Prob \\
\hline $\ln T O$ & -0.517191 & 0.073957 & -6.993099 & 0.0000 \\
\hline $\ln K O F$ & 1.743026 & 0.181185 & 9.620146 & 0.0000 \\
\hline \multirow[t]{2}{*}{$C$} & -2.712586 & 0.505697 & -5.364049 & 0.0000 \\
\hline & $R^{2}$ & 0.824288 & $A d j . R^{2}$ & 0.80794 \\
\hline \multicolumn{5}{|c|}{ CCR Test Results } \\
\hline \multirow[t]{2}{*}{ Variables } & Dependent Variable: 1 & & & \\
\hline & Coefficient & Standard Error & t-statistics & Prob \\
\hline $\ln T O$ & -0.550175 & 0.067645 & -8.133260 & 0.0000 \\
\hline $\ln K O F$ & 1.827934 & 0.168677 & 10.83692 & 0.0000 \\
\hline \multirow[t]{2}{*}{$C$} & -2.941216 & 0.479512 & -6.133767 & 0.0000 \\
\hline & $R^{2}$ & 0.743173 & $A d j . R^{2}$ & 0.73176 \\
\hline
\end{tabular}

\section{Bootstrap Causality Test Results}

The bootstrap causality test developed by Hacker and Hatemi-J (2012) is presented in Table 6. In this study, the optimal lag length is determined by HJC information criteria.

In Hacker and Hatemi-J (2012) bootstrap causality test, the basic hypothesis states no causality relationship between the variables. From this point of view, when the MWALD test statistics values are greater than the cratical values obtained by the bootstrap method, the basic hypothesis stating no causal relationship between the variables is rejected. The findings obtained from the causality analysis show a one-way causality relationship from trade openness to government size. 
Table 6. Bootstrap causality test results

\begin{tabular}{lccccc}
\hline & VAR(p) & MWALD & \multicolumn{3}{c}{ Bootstrap critical values } \\
\cline { 4 - 6 } $\ln T O \rightarrow \ln G E$ & 1 & $6.972^{*}$ & 7.633 & 4.321 & 2.927 \\
\hline $\ln K O F \rightarrow \ln G E$ & 1 & 0.095 & 7.069 & 4.032 & 2.870 \\
\hline $\ln G E \rightarrow \ln T O$ & 1 & 0.523 & 7.438 & 4.246 & 2.990 \\
\hline $\ln K O F \rightarrow \ln T O$ & 1 & 0.007 & 7.321 & 4.158 & 2.886 \\
\hline $\ln G E \rightarrow \ln K O F$ & 1 & 0.223 & 7.458 & 4.074 & 2.875 \\
\hline $\ln T O \rightarrow \ln K O F$ & 1 & 0.168 & 7.524 & 4.152 & 2.868 \\
\hline
\end{tabular}

Note: $(1){ }^{*}$ represent the significance in $5 \%$. (2) The optimal lag length this determined as 1 according to HJC information criteria. (3) Bootstrap critical values are obtained by 10.000 replications.

\section{Conclusion}

In this study, the effects of trade openness and globalization on government expenditures are examined. This relationship is explained based on the efficiency and compensation hypotheses in the literature. In this study, whether trade openness and globalization affect government expenditures is examined in the case of Turkey, with annual data for the period 1970-2018. The study uses RALS cointegration and bootstrap causality tests to test whether Turkey's efficiency and compensation hypotheses are valid.

Two important results are obtained in the study. The first of the results is that globalization has a positive effect on government expenditures. This result is consistent with the compensation hypothesis. The positive effect of globalization on government expenditures shows that governments increase spending to offset the risks and uncertainties caused by greater exposure to global markets. The second result shows that trade openness negatively affects government expenditures. This result is consistent with the efficiency hypothesis. This result is consistent with the studies of Cusack (1997), Liberati (2007), Altay and Aysu (2013). The negative effect of trade openness shows that governments reduce expenditures due to the pressures on tax revenues caused by increased trade openness. This result is consistent with the study of Meinhard and Partake (2012). In addition, according to the results of the bootstrap causality test, it is found that there is a one-way causality relationship from trade openness to government expenditures. Further studies to test the validity of the compensation and efficiency hypotheses could examine the impact of trade openness and globalization and its subcomponents on the disaggregated government expenditures of countries, particularly on the composition of social expenditures.

\section{Ethics Committee Permission}

This article is not part of a working group that requires ethical committee approval.

\section{Contribution Rate Statement}

The authors contributed equally to the article. 
Zerrin KILIÇARSLAN, Cüneyt DUMRUL \& Yasemin DUMRUL

\section{Conflict of Interest Statement}

There is no conflict of interest between the authors.

谈谈 


\section{Kaynakça}

Alesina, A., \& Wacziarg, R. (1998). Openness, country size and government. Journal of Public Economics, 69(3), 305-321.

Altay, A., \& Aysu, A. (2013). Etkinlik ve telafi edici etki hipotezi: Seçilmiş ülkeler üzerine ampirik bir inceleme. TISK Akademi, 8(15), 131-154.

Anderson, E., \& Obeng, S. (2021). Globalisation and government spending: Evidence for the 'hyperglobalisation' of the 1990s and 2000s. The World Economy, 44(5), 1144-1176.

Aydogus, I., \& Topcu, M. (2013). An investigation of co-integration and causality between trade openness and government size in Turkey. International Journal of Economics and Financial Issues, 3(2), 319-323.

Benarroch, M., \& Pandey, M. (2008). Trade openness and government size. Economics Letters, 101(3), 157159.

Bergh, A. (2019). The compensation hypothes is revisited and reversed. IFN Working Paper, No. 1273, Research Institute of Industrial Economics (IFN), Stockholm.

Cameron, D. R. (1978). The expansion of the public economy: A comparative analysis. American political science review, 72(04), 1243-1261.

Cusack, T. (1997). Partisan politics and public finance: Changes in public spending in the industrialized democracies 1955-1989. Public Choice, 91(3-4), 375-395.

Dreher, A., Sturm, J. E., \& Ursprung, H. W. (2008). The impact of globalization on the composition of government expenditures: Evidence from panel data. Public Choice, 134(3-4), 263-292.

Epifani, P., \& Gancia, G. (2009). Openness, government size and the terms of trade. Review of Economic Studies, 76(2), 629-668.

Garen, J., \& Trask, K. (2005). Do more open economies have bigger governments? Another look. Journal of development economics, 77(2), 533-551.

Garrett, G. (2001). Globalization and government spending around the world. Studies in Comparative International Development, 35(4), 3-29.

Gastaldi, F., \& Liberati, P. (2009). Economic integration and public policies: A review of the empirical literature. SIEP Working Paper 619.

Gemmell, N., Kneller, R., \& Sanz, I. (2008). Foreign investment, international trade and the size and structure of public expenditures. European Journal of Political Economy, 24(1), 151-171.

Genç, M. C., \& Telatar, O. M. (2015). Telafi hipotezi Türkiye için geçerli midir?. International Conference on Eurasian Economies, 437-444.

Gözgör, G., Bilgin, M. H., \& Zimmermann, K. F. (2019). Public employment decline in developing countries in the 21st century: The role of globalization. Economics Letters, 184, 108608.

Hacker, S., \& Hatemi, J. A. (2012). A bootstrap test for causality with endogenous lag length choice: Theory and application in Finance. Journal of Economic Studies,39(2), 144-160.

Hatemi-J, A., \& Uddin, G. S. (2014). On the causal nexus of remittances and poverty reduction in Bangladesh. Applied Economics, 46(4), 374-382. 
Hatemi-J, A. (2003). A new method to choose optimal lag order in stable and unstable VAR models. Applied Economics Letters, 10(3), 135-137.

Hatemi-J, A. (2008). Forecasting properties of a new method to determine optimal lag order in stable and unstable VAR models. Applied Economics Letters, 15(4), 239-243.

Im, K.S., Lee, J., \& Tieslau M. A. (2014). More powerful unit root tests with non-normal errors. In R. C. Sickles\&W. C. Horrace (Eds.), Festschrift in honor of Peter Schmidt (pp. 315-342). Springer.

Im, K. S., \& Schmidt, P. (2008). More efficient estimation under non-normality when higher moments do not depend on the regressors, using residual augmented least squares. Journal of Econometrics, 144(1), 219-233.

Kim, D. H., Suen, Y. B., Lin, S. C., \& Hsieh, J. (2018). Government size, government debt and globalization. Applied Economics, 50(25), 2792-2803.

Kueh, J. S. H., Puah, C. H., \& Wong, C. M. (2008). Bounds estimation for trade openness and government expenditure nexus of ASEAN-4 countries. MPRA Paper 12351, University Library of Munich, Germany.

Lee, H., Lee J., \& Im, K. (2015). More powerful co-integration tests with non-normal errors. Studies in Nonlinear Dynamics \& Econometrics, 19(4), 397-413.

Liberati, P. (2007). Trade openness, capital openness and government size. Journal of Public Policy, 27(2), 215-247.

Meinhard, S., \& Potrafke, N. (2012). The globalization-welfare state nexus reconsidered. Review of International Economics, 20(2), 271-287.

Özek, Y., \& Bayat, T. (2020). BRICS ülkelerinde etkinlik ve telafi edici etki hipotezlerinin geçerliliğinin test edilmesi. Adryaman Üniversitesi Sosyal Bilimler Enstitüsü Dergisi, 35, 719-741.

Park, J. Y. (1992). Canonical cointegrating regressions. Econometrica: Journal of the Econometric Society, 60(1), 119-143.

Pata, U. K., \& Süleyman Y. (2020). Telafi ve etkinlik hipotezlerinin RALS-EG eş-bütünleşme yaklaşımı ile testi: Türkiye örneği. Dicle Üniversitesi Sosyal Bilimler Enstitüsü Dergisi, 24, 82-95.

Phillips, P. C. B., \& Hansen, B. E. (1990). Statistical inference in instrumental variables regression with I(1) Processes. Review of Economic Studies, 57, 99-125.

Potrafke, N. (2009). Did globalization restrict partisan politics? An empirical evaluation of social expenditures in a panel of OECD countries. Public Choice, 140(1-2), 105-124.

Rodrik, D. (1998), Why do more open economies have bigger governments?.Journal of Political Economy, 106(5), 997-1032.

Sener, S., Bayrakdar, S., \& Hacioglu, V. (2015). The analysis for the validity of compensation and efficiency hypotheses in Turkey between 1975 and 2013. Procedia-Social and Behavioral Sciences, 195, 624-631.

Stock, J. H., \& Watson, M. W. (1993). A simple estimator of cointegrating vectors in higher order integrated systems. Econometrica: Journal of the Econometric Society, 61(4), 783-820. 
Yılancı, V., \& Aydın, M. (2018). The impact of female college enrollment on economic growth in Turkey: A RALS-EG co-integration test approach. UïïD-IJEAS, Prof. Dr. Harun Terzi Special Issue, 101112.

Yıldız, Ü. (2019). Küreselleşme ile kamu büyüklüğü arasındaki nedensellik ilişkisi: OECD Ülkeleri örneği. Mali Çözüm Dergisi / Financial Analysis, 29(155), 81-103.

Zakaria, M., \& Shakoor, S. (2011). Relationship between government size and trade openness: Evidence from Pakistan. Transition Studies Review, 18, 328-341.

Zeren, F., \& Ergün, S. (2013). Ticari açıklık ve kamu büyüklüğü ilişkisi: Panel nedensellik testi. Atatürk Üniversitesi İktisadi ve İdari Bilimler Dergisi, 27(4), 229-240.

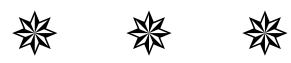

